\title{
Amaranthus spinosus water extract directly stimulates proliferation of B lymphocytes in vitro
}

\author{
Bi-Fong Lin ${ }^{\mathrm{a}}$, Bor-Luen Chiang ${ }^{\mathrm{b}}$, Jin-Yuarn Lin ${ }^{\mathrm{c}, *}$ \\ ${ }^{a}$ Department of Biochemical Science and Technology, Institute of Microbiology and Biochemistry, College of Life Science, \\ National Taiwan University, Taiwan, Republic of China (ROC) \\ ${ }^{\mathrm{b}}$ Graduate Institute of Clinical Medicine, College of Medicine, National Taiwan University, Taiwan, Republic of China (ROC) \\ ${ }^{\mathrm{c}}$ Department of Food Science, College of Agriculture and Natural Resources, National Chung Hsing University, 250 Kuokuang Road, \\ Taichung 40227, Taiwan, Republic of China (ROC)
}

Received 28 October 2004; received in revised form 26 November 2004; accepted 1 December 2004

\begin{abstract}
Amaranthus spinosus Linn. (thorny amaranth), a plant that grows in the wild fields of Taiwan, is extensively used in Chinese traditional medicine to treat diabetes. There have been no published studies on the immunological effects of $A$. spinosus. To determine whether A. spinosus has immuno-modulatory effects and clarify which types of immune effector cells are stimulated in vitro, we investigated the stimulatory effect of wild A. spinosus water extract (WASWE) on spleen cells from female BALB/c mice. We found that WASWE significantly stimulated splenocyte proliferation. However, isolated B lymphocytes, but not T lymphocytes, could be stimulated by WASWE in a dose response manner. After sequentially purifying WASWE, a novel immuno-stimulating protein (GF1) with a molecular weight of $313 \mathrm{kDa}$ was obtained. The immuno-stimulating activity of the purified protein (GF1) was 309 times higher than that of WASWE. These results indicate that WASWE does indeed exhibit immuno-stimulating activity via directly stimulating B lymphocyte activation in vitro. Further, these results suggest that the immuno-stimulating effects of WASWE might lead to B lymphocyte activation and subsequent T cell proliferation in vitro. These results are potentially valuable for future nutraceutical and immuno-pharmacological use of WASWE or its purified fractions. (C) 2004 Elsevier B.V. All rights reserved.
\end{abstract}

* Corresponding author. Department of Food Science, College of Agriculture and Natural Resources, National Chung Hsing University, 250 Kuokuang Road, Taichung 40227, Taiwan, Republic of China (ROC). Tel.: +886 422851857 ; fax: +886 422851857.

E-mail address: jinlin@nchu.edu.tw (J.-Y. Lin).

\section{Introduction}

Increasing the body's immunity in defending against diseases such as infections and tumors has become a major concern to many people in recent years [1-4]. More research has been focused on exploring the immune-enhancing effect of possible dietary substan- 
ces. The growth of herbal medicines or functional foods based on natural medicinal plants has gained rapid development in recent years around the globe. The functional products with specific health benefits from immunological activity have been the fastestgrowing sector, moving swiftly into the mainstream. Recently, it was found that active thermally stable proteoglycans with molecular masses exceeding $100 \mathrm{kDa}$ could be extracted from shark cartilage. These proteoglycans exhibit powerful immuno-stimulating activity in vitro [5]. Ginkgo biloba extract EGb 761 demonstrated immuno-stimulating activity on the nonspecific and humoral immune responses in a hypothalamicpituitary-adrenal axis activation model in stressed rats [6]. Folk herb extracts from Aeginetia indica Roxbert extensively used in Thailand demonstrate a $\mathrm{T}$ cell stimulatory activity in vivo [7]. Neem (Azadirachta indica) leaf was found to have a prominent role in the murine Ehlich carcinoma and B-16 melanoma cellular immune function, causing prophylactic growth inhibition of the tumor cells [8]. Dioscoreae rhizoma methanol extract (root of Dioscorea tokoro MAKINO) is traditionally used for the treatment of arthritis, muscular pain and urinary diseases in oriental medicine which significantly reduces pro-inflammatory cytokines and is a mediator in the synoviocytes of rheumatoid arthritis [9]. Chinese herbal medicine, Xiao-Qing-Long-Tang has confirmed the immunomodulatory effect reducing bronchial inflammation in allergen-sensitized mice $[10,11]$. Most of the Chinese medicinal ingredients promote cellular or humoral immune responses by promoting lymphocyte proliferation and serum antibody titer [12]. However, herbal medicines and their ingredients or bioactive substances in foods, may exert differential immuno-modulation $[13,14]$. Searching for immuno-modulatory materials and characterizing the immune enhancement effects may have great potential in future practical applications for immuno-pharmacology. Amaranthus spinosus Linn. (thorny amaranth), a plant that grows in the wild fields of Taiwan, is extensively served as Chinese traditional medicine or wild vegetables to treat diabetes. However, there have been no published studies on the immunological effects of $A$. spinosus indigenous to Taiwan. This paper studies whether A. spinosus has immuno-modulatory effects and clarifies which types of immune effector cells are stimulated by wild $A$. spinosus water extract (WASWE).
It is difficult to wholly evaluate both the cellular and humoral immune responses in vivo. However, feasible in vitro assays to screen the lymphoproliferation activity of the possible daily food items and some of their active constituents are documented $[5,15,16]$. In this study, wild A. spinosus water extract (WASWE) was investigated for its stimulatory responses on immune effector cells using primary splenocyte culture from female BALB/c mice. To further characterize the possible immuno-modulatory components in WASWE, we also report on the isolation, basic physicochemical properties and immuno-stimulating activity of WASWE in vitro.

\section{Materials and methods}

\subsection{Wild A. spinosus Linn. water extract (WASWE) preparation}

A. spinosus leaves were weighed and chopped. After the same weight of deionized water was added, the sample was stirred in a Waring blender to extract the water-soluble constituent. The slurry was then centrifuged at $9000 \times \mathrm{g}\left(4^{\circ} \mathrm{C}\right)$ for $30 \mathrm{~min}$. A part of the supernatant was directly lyophilized to obtain a crude WASWE powder and the remainder of the supernatant was heated at $100{ }^{\circ} \mathrm{C}$ for $30 \mathrm{~min}$ and then lyophilized to harvest the heat-treated WASWE powder. The yield of crude extract was calculated by the recovery of lyophilized powder and expressed as grams of WASWE/100 $\mathrm{g}$ of fresh vegetables.

\subsection{WASWE chromatographic purification}

\subsubsection{DEAE sephacel}

Ion exchange: DEAE sephacel (Pharmacia Biotech) medium was used to purify crude WASWE. After applying the crude sample (WASWE), the column $(1.5 \mathrm{~cm} \times 12 \mathrm{~cm}$, Econo-Pac column, BioRad Laboratories) was eluted at a flow rate of $1.0 \mathrm{ml} /$ min with 2 bed volumes of deionized water, $0.1 \mathrm{M}$ $\mathrm{NaCl}, 0.3 \mathrm{M} \mathrm{NaCl}, 0.5 \mathrm{M} \mathrm{NaCl}, 1.0 \mathrm{M} \mathrm{NaCl}, 2.0 \mathrm{M}$ $\mathrm{NaCl}, 1.0 \mathrm{~N} \mathrm{NaOH}$ (washing column), and $1.0 \mathrm{~N} \mathrm{HCl}$ (washing column), respectively. The eluent was collected using a fraction collector (Gilson, model 203) and detected by absorbance at $280 \mathrm{~nm}$. The material was resolved into seven major peaks: 
IF1 IF7. Each fraction was lyophilized and analyzed for immuno-stimulating activity. The yields of ion exchange fractions (IF1 IF7) were calculated by the recovery of lyophilized powder and expressed as grams of IF1 IF7/100 $\mathrm{g}$ of WASWE.

\subsubsection{Sepharose $C L-6 B$}

The starting material (active fraction eluted from ion exchange column) was applied in a Sepharose CL$6 \mathrm{~B}$ column (Pharmacia Biotech) to further purify the active ion exchange fraction. The column (2.6 $\mathrm{cm} \times 100 \mathrm{~cm}$ ) was eluted with deionized water at a flow rate of $1.3 \mathrm{ml} / \mathrm{min}$. Each tube collected about 240 drops of eluent. Each fraction was lyophilized and tested for the stimulation index of cell proliferation. The molecular weight of each fraction was calibrated with a standard molecular weight kit. The yields of gel filtration fractions (GF1 GF2) were calculated by the recovery of lyophilized powder and expressed as grams of GF1 GF2/100 $\mathrm{g}$ of IF4.

\subsection{Protein content analysis}

The protein content of the purified sample was analyzed using the BCA (bicinchoninic acid) protein assay kit (product No. 23225, Pierce), according to the accompanying instructions, using a 96-well microtiter plate. Briefly, aliquots of $25 \mu \mathrm{l}$ of each standards (bovine serum albumin, BSA, product No. 23209, Pierce) or unknown samples were pipetted into the appropriate microwell plate wells (Nunc). Aliquots of $200 \mu \mathrm{l}$ of the working reagent (containing sodium carbonate, sodium bicarbonate, bicinchoninic acid, sodium tartrate in $0.1 \mathrm{M}$ sodium hydroxide and cupric sulfate) were added to each well and mixed the plate well on a plate shaker for $0.5 \mathrm{~min}$. Then, the plate was covered and incubated at $37{ }^{\circ} \mathrm{C}$ for $30 \mathrm{~min}$. After incubation, the plate was cooled to room temperature and measured the absorbance at or near $562 \mathrm{~nm}$ on a plate reader (ELISA reader, ASYS Hitech, Austria). Using the standard curve, the protein concentration for each unknown sample was determined.

\subsection{In vitro biological assessment}

\subsubsection{Experimental animals for primary splenocytes}

$\mathrm{BALB} / \mathrm{c}$ mice (female, adult) were purchased from the Laboratory Animal Center, College of Medicine,
National Taiwan University and maintained in the Department of Biochemical Science and Technology, College of Life Science, National Taiwan University. The mice were housed and fed a standard Lab diet (normal chow diet) individually. The animal room was kept on a 12-h-light and 12-h-dark cycle. Constant temperature $\left(25 \pm 2{ }^{\circ} \mathrm{C}\right)$ and humidity were maintained. The animals (8- to 10 -week old) were sacrificed using $\mathrm{CO}_{2}$ inhalation to obtain spleens. The abdominal cavities were opened aseptically and the spleens were removed.

\subsubsection{Splenocyte proliferation stimulation}

The spleen cell proliferation response was assayed as described previously $[17,18]$. Briefly, spleens were removed aseptically from $B A L B / c$ mice. Single spleen cells were prepared by lysing the red blood cells. Splenocytes were isolated from each animal and adjusted to $1 \times 10^{7}$ cells $/ \mathrm{ml}$ in TCM medium. Splenocytes $(50 \mu \mathrm{l} /$ well $)$ without or with mitogens $(50 \mu \mathrm{l} /$ well), such as phytohemagglutinin (PHA, $20 \mu \mathrm{g} / \mathrm{ml}$ in TCM medium, Sigma), lipopolysaccharide (LPS, 10 $\mu \mathrm{g} / \mathrm{ml}$ in TCM medium, Sigma), WASWE $(10,40$, 200, 1000, 2500, $5000 \mu \mathrm{g} / \mathrm{ml}$ in TCM medium, respectively), IF1 IF7 (10, 40, 200, 1000, $2500 \mu \mathrm{g} /$ $\mathrm{ml}$, respectively) or GF1 GF2 (1.0, 5.0, 10.0, $20.0 \mu \mathrm{g} /$ $\mathrm{ml}$ in TCM medium, respectively) were plated in 96well microtiter plates. The plates were incubated at 37 ${ }^{\circ} \mathrm{C}$ in a humidified incubator with $5 \% \mathrm{CO}_{2}$ and $95 \%$ air for $48 \mathrm{~h}$. The cells were then pulsed with $\left[{ }^{3} \mathrm{H}\right]-$ thymidine $(1 \mu \mathrm{Ci} /$ well in $10 \mu \mathrm{l} \mathrm{TCM}$ medium). After $24 \mathrm{~h}$, the cells were harvested using a semi automated sample cell harvester (FILTERMATE 196 PACKARD). The radioactivity was determined using a Direct Beta Counter (MATRIX 96, PACKARD). The stimulation index (S.I.) was expressed as S.I. $=$ (mitogen $_{\text {cpm }}-$ blank $\left._{\mathrm{cpm}}\right) /\left(\right.$ control $_{\mathrm{cpm}}-$ blank $\left._{\mathrm{cpm}}\right)$. Each value was presented as mean \pm S.E. $(n=6)$.

\subsection{3. $T$ and $B$ cell specific proliferation responses in total splenocytes from $B A L B / c$ mice \\ To further define the lymphocyte population stimu- lated by WASWE, bromodeoxyuridine (BrdU) cell incorporation was performed and analyzed with FACS (flow cytometry) analysis [19,20]. After the spleen cells were stimulated by WASWE $(1250 \mu \mathrm{g} / \mathrm{ml})$, LPS $(10 \mu \mathrm{g} / \mathrm{ml})$ and PHA $(10 \mu \mathrm{g} / \mathrm{ml})$, respectively, for $48 \mathrm{~h}$, $10 \mu \mathrm{M}$ bromodeoxyuridine (BrdU; Becton Dickinson)}


was added and the cells incubated for another $24 \mathrm{~h}$. The cells were then fixed with $1 \%$ paraformaldehyde and split into several portions to clarify the proliferation percentage by cell surface markers on specific cell. Parts of the cells were stained with fluoroesceinisothiocyanate (FITC)-conjugated anti-BrdU antibody and phycoerythin (PE)-conjugated anti-B220 antibody to detect the proliferation of $\mathrm{B}$ cells. The rest of the cells were stained with FITC-conjugated anti-BrdU antibody and PE-conjugated anti-CD3 antibody to detect the proliferation of $\mathrm{T}$ cells. After that, the harvested cells were subjected to flow cytometry (FACS) analysis (Becton Deckinson), respectively.

\subsubsection{T and B cell isolation from splenocytes}

To further confirm which types of lymphocytes were directly stimulated by WASWE, T and B cells were isolated from the spleen cells of female BALB/c mice [19-21]. T cell isolation is based on its less binding activity with nylon wool than that of other cells. T cells (nylon wool nonadherent cells) were separated by passing the spleen cells through a nylon wool column packed in a $10 \mathrm{ml}$ syringe. After incubation of total splenocytes in the column at $37{ }^{\circ} \mathrm{C}$ for $1 \mathrm{~h}$, T cells were collected by eluting the column with $10 \mathrm{ml}$ TCM medium. B cells (T depleted spleen cells) were isolated by complement-mediated $\mathrm{T}$ cell lysis using anti-mouse Thy 1.2 antibody plus rabbit complement (CEDARLANE Laboratory) treatment. The purity of the isolated $\mathrm{T}$ and $\mathrm{B}$ cells were further analyzed by FACS analysis. Total splenocytes, isolated $\mathrm{B}$ cells, and isolated T cells (original cell density: $2 \times 10^{6}$ cells $/ \mathrm{ml}$ ) were treated with WASWE (final concentration: $1250,2500 \mu \mathrm{g} / \mathrm{ml}$ ) and quantified with the $\left[{ }^{3} \mathrm{H}\right]$-thymidine incorporation method to evaluate their proliferation rates as described above. The isolated $\mathrm{T}$ cells were also incubated with $\gamma$-irradiated (2000 rad) antigen-presenting cells (APC, syngeneic splenocytes).

\subsection{Statistical analysis}

Data were analyzed by the Windows SAS program (Version 6.12). Data are expressed as mean \pm S.E. and analyzed statistically using ANOVA followed, if justified by the statistical probability $(P<0.05)$, by Duncan's New Multiple Range test. Differences were considered statistically significant if $P<0.05$.

\section{Results}

\subsection{WASWE effect on cell proliferation of total splenocytes from female $B A L B / c$ mice}

Splenocyte proliferation from inbred BALB/c mice species cultured in the presence of WASWE was evaluated. The highest stimulation activity was found at the concentration of $1250 \mu \mathrm{g}$ WASWE/ml (Fig. 1). It was found that WASWE significantly stimulated splenocyte proliferation in a dose response manner. However, WASWE lost its immuno-stimulating activity after it was heated at $100{ }^{\circ} \mathrm{C}$ for $30 \mathrm{~min}$ (data not shown). To clarify which types of immune effector cells in the spleen were being stimulated by WASWE, the proliferation of lymphocyte subset in total splenocyte culture was studied. The CD3+ and B220+ surface markers on proliferation cells of total splenocyte culture were detected by FACS. Both B $(\mathrm{B} 220+)$ and $\mathrm{T}$ cells $(\mathrm{CD} 3+)$ in total splenocyte culture were stimulated simultaneously by WASWE at the concentration of $1250 \mu \mathrm{g} / \mathrm{ml}$ (Fig. 2). However, the proliferation rate of $\mathrm{B}$ cells $(14.85 \pm 2.44 \%)$ exceeded that for $\mathrm{T}$ cells $(7.49 \pm 3.12 \%)$ at the indicated WASWE concentration on the third incubation day. Stimulatory activities by LPS (a B cell mitogen) and PHA (a T cell mitogen) to both $\mathrm{B}$ and $\mathrm{T}$ cell subsets were higher than that for WASWE. B and $\mathrm{T}$ cell stimulation in the presence of LPS revealed significant differences from the Sham (control). B cell stimulation in the presence of WASWE revealed significant differences from the Sham (control). Even though WASWE demonstrated immuno-stimulating activity to total splenocytes including both $\mathrm{B}$ and $\mathrm{T}$ cells, it is not clear whether WASWE stimulated lymphocyte proliferation of both B and T cells [20].

\subsection{WASWE effect on purified populations of B cells and $T$ cells obtained from total splenocytes}

To avoid secondary B and T lymphocyte signals being disturbed by each other on the proliferation rate, $\mathrm{B}$ and T cells in the total splenocytes were isolated. The cellular purity of B and T cells was assayed by FACS analysis. It was found that the cell constitutes of splenocytes, isolated B and T cells, contained $41.54 \%$ B cells and $47.11 \%$ T cells, $82.34 \%$ B cells and $4.15 \%$ $\mathrm{T}$ cells, and $88.85 \% \mathrm{~T}$ cells and $2.89 \% \mathrm{~B}$ cells, 


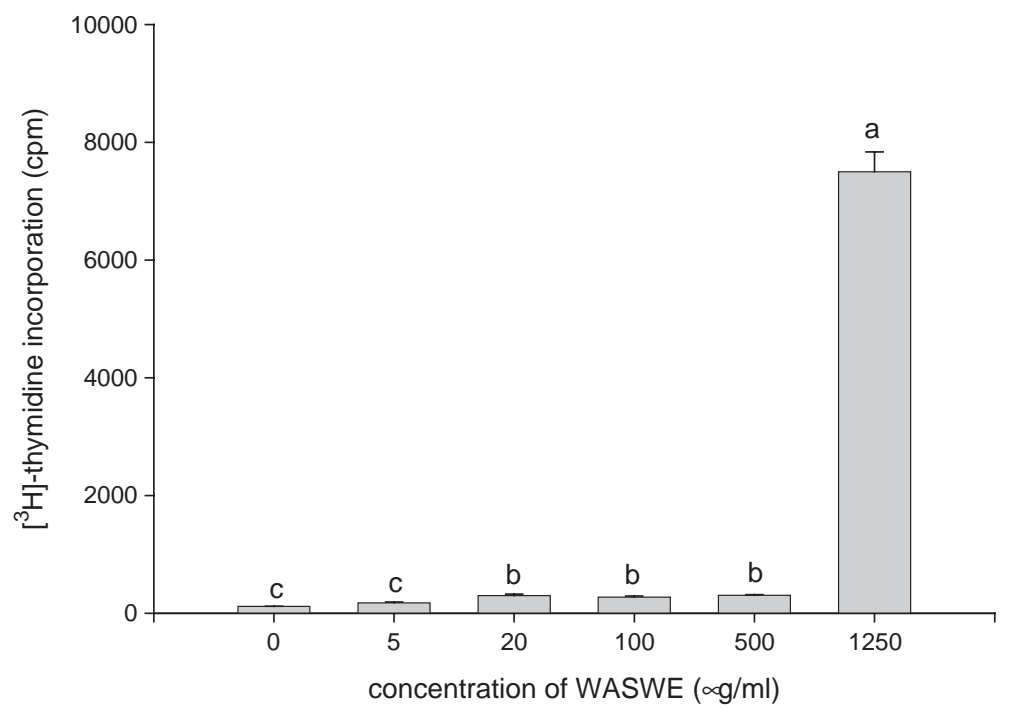

Fig. 1. Effects of WASWE on proliferation of total splenocytes from BALB/c mice. Data are assayed using ANOVA. Each bar represents the mean value \pm S.E. obtained from six separated mice. Within each bars graph, bars not sharing a letter are significantly different $(P<0.05)$ according to Duncan's New Multiple Range test.

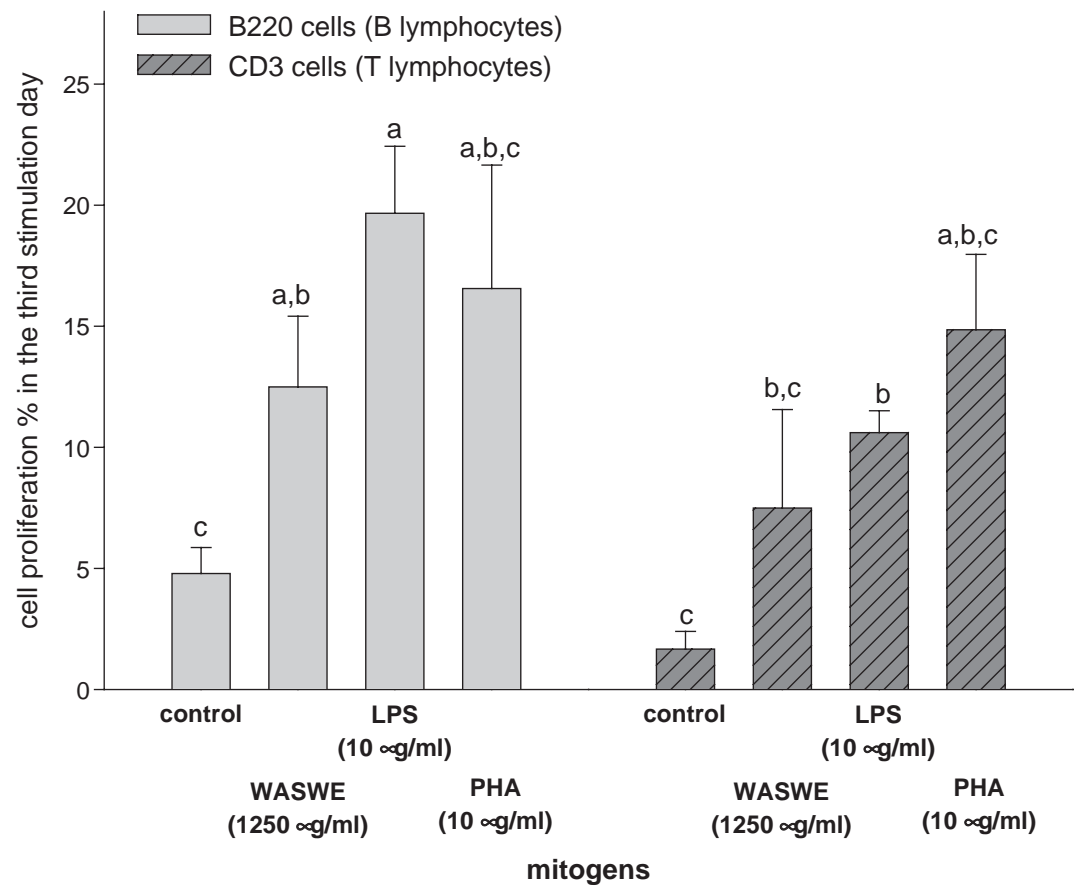

Fig. 2. Effects of WASWE, LPS (a B cell mitogen), and PHA (a T cell mitogen) on proliferation of separated populations (B cells or T cells) according to the surface marker distribution on cell proliferation in the entire splenocyte culture from BALB/c mice detected with FACS at the third day of incubation. Original cell density was $5.0 \times 10^{6}$ cells $/ \mathrm{ml}$. Cell proliferation percentages were calculated on the basis of the number of lymphocytes found in each quadrant. Data are assayed using ANOVA. Each bar represents the mean value \pm S.E. obtained from three separated mice. Within each bars graph of separated populations (B cells or T cells), bars not sharing a letter are significantly different $(P<0.05)$ according to Duncan's New Multiple Range test. 
respectively (Fig. 3). The cellular purity of the individual subpopulations in the purified $\mathrm{B}$ and $\mathrm{T}$ cell populations increased by about 2 folds. The total number of splenocytes, isolated $\mathrm{B}$ and $\mathrm{T}$ cells (cell

(a) total splenocytes

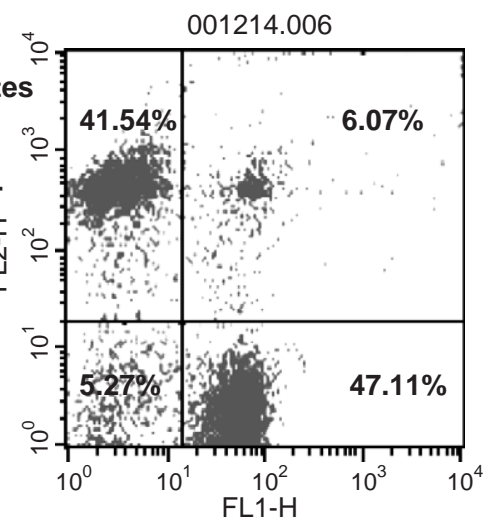

(b) isolated B cells

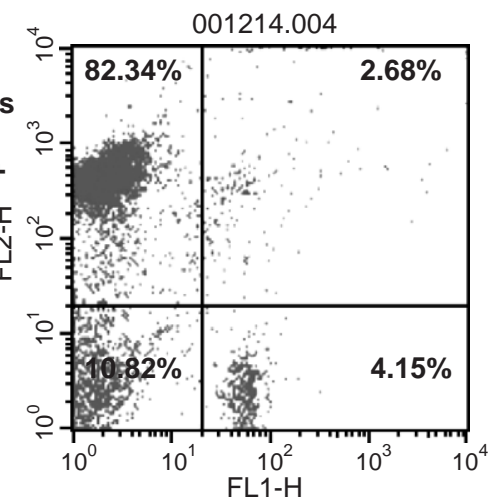

(c) isolated T cells

$$
\stackrel{+}{\circ}
$$
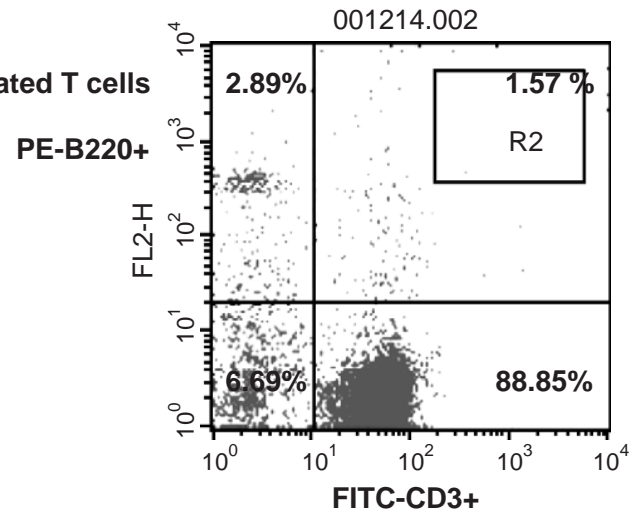

Fig. 3. Cellular analysis of B and T lymphocyte subsets in (a) total splenocytes, (b) isolated B cells and (c) isolated T cells. Total splenocytes were directly obtained from female BALB/c mice. Isolated B cells were obtained after they were treated using the complement lysis method. Isolated $\mathrm{T}$ cells were enriched in a nylon wool column. density: $2.0 \times 10^{6}$ cells $/ \mathrm{ml}$ ), respectively, were further exposed to different concentrations of WASWE for 72 h. We determined the stimulation index (S.I.) for the total (unpurified) splenocytes, isolated (purified) B and (purified) T cells and they were 6.00, 2.08, and 0.99 at a concentration of $1250 \mu \mathrm{g} / \mathrm{ml}$ WASWE and 2.50, 4.85, and -0.41 , respectively, at a concentration of $2500 \mu \mathrm{g} /$ $\mathrm{ml}$ WASWE. The $\mathrm{B}$ and $\mathrm{T}$ cell subpopulations responded differently to stimulation by WASWE. Higher WASWE concentrations $(2500 \mu \mathrm{g} / \mathrm{ml})$ caused a cytotoxic effect in purified T cells. Purified B cells, but not T cells, could be stimulated with WASWE in a dose-dependent manner. The splenocytes had a much higher proliferation rate than that of individual purified $B$ or $T$ cells at the concentration of $1250 \mu \mathrm{g} / \mathrm{ml}$ WASWE, suggesting some interactions occurred between these two cells. These results suggest that WASWE exerted a direct stimulatory effect on B cells. $\mathrm{T}$ cells seemed to have a co-stimulatory effect on $\mathrm{B}$ cells. T cells in bulk splenocytes might be activated via secondary signaling from stimulated B cells, leading to T cell proliferation. Since LPS and PHA are powerful B and $\mathrm{T}$ lymphocyte stimulants, they were chosen as positive controls for lymphocyte proliferation in this experiment. We found that the LPS $(5 \mu \mathrm{g} / \mathrm{ml})$ stimulation index on isolated $\mathrm{B}$ and T cells were 573.83 and 3.47 , respectively. The PHA $(10 \mu \mathrm{g} / \mathrm{ml})$ stimulation index on isolated B and T cells were 19.63 and 72.09, respectively. These results were in accordance with our prediction. It was also verified that isolated lymphocyte cultures in this experimental model were workable and believable. Stimulation index of total splenocytes stimulated by LPS or PHA was higher than that of individual purified $\mathrm{T}$ or $\mathrm{B}$ cells, suggesting some interdependence between these two cells.

\subsection{Purification of immuno-stimulating components in WASWE}

\subsubsection{Ion exchange chromatography}

To exploit the bioactive substances that stimulate splenocyte proliferation in vitro, WASWE was first partially purified using DEAE sephacel ion exchange. Seven fractions (IF1 IF7) were obtained (Fig. 4) and conducted to test their immuno-stimulating activity. The tests demonstrated that the fourth fraction, IF4, was the active fraction that stimulated splenocyte proliferation (Fig. 5). Fig. 5 shows that crude 


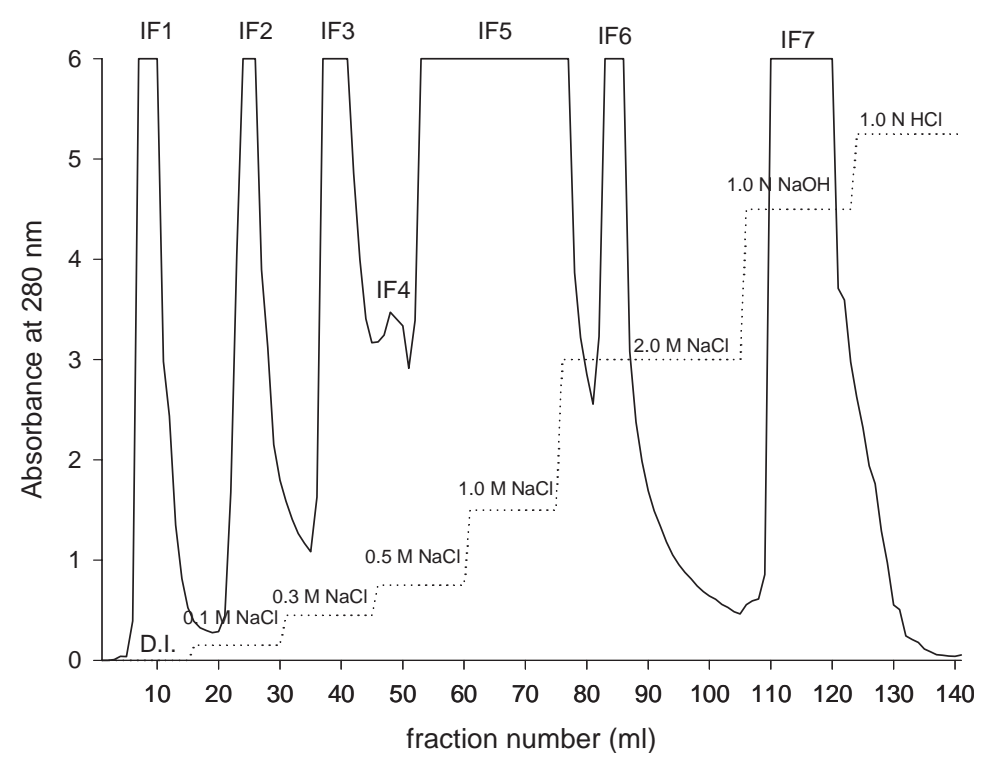

Fig. 4. Chromatogram of WASWE by step gradient ion exchange chromatography using DEAE sephacel media. Column size: $1.5 \mathrm{~cm} \times 12 \mathrm{~cm}$ $(20 \mathrm{ml})$. Elution volume of each gradient exchange was $40 \mathrm{ml}$ at a flow rate of $1.0 \mathrm{ml} / \mathrm{min}$.

WASWE and IF4 indeed demonstrated immunostimulating activity on splenocyte cultures at the $1250 \mu \mathrm{g} / \mathrm{ml}$ WASWE and $5 \times 10^{6}$ cells $/ \mathrm{ml}$ concentration. The radioactivity uptake $(\mathrm{cpm})$ by the total splenocytes stimulated by crude WASWE and IF4 was $7500 \pm 335$ and $12,902 \pm 382$ respectively.

\subsubsection{Gel filtration chromatography}

IF4 was further purified using a gel filtration column packed with Sepharose CL-6B. Gel-filtrated chromatogram of IF4 was consisted of two major fractions, GF1 and GF2 (Fig. 6a). As compared to the gel-filtrated chromatograms of gel filtration standard,

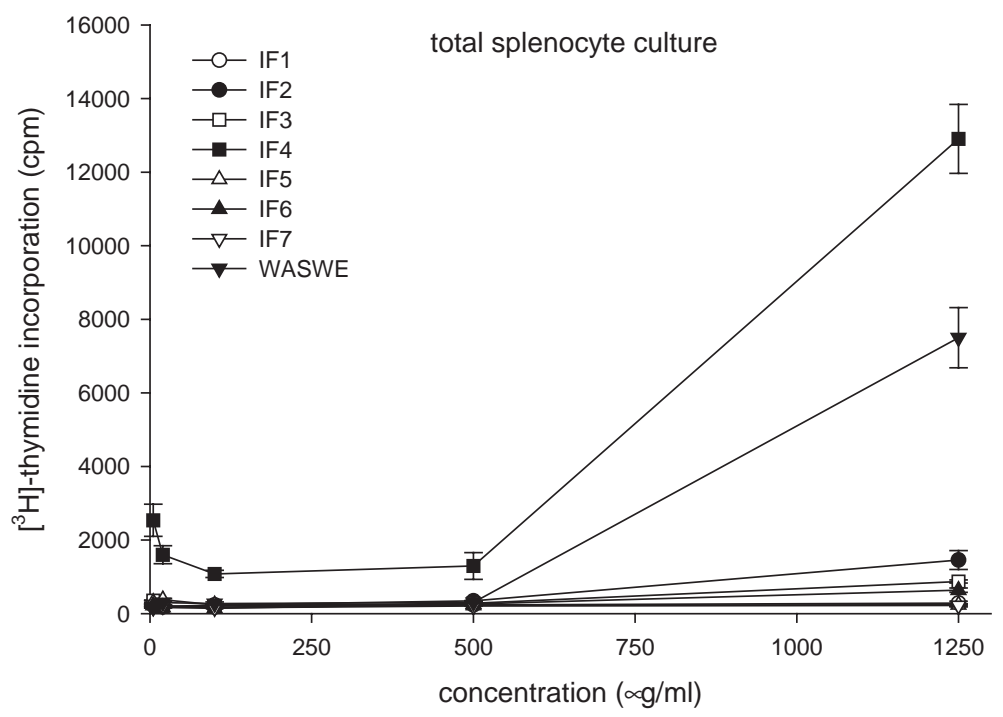

Fig. 5. Effects of different WASWE preparations on total splenocyte proliferation from BALB/c mice. Original cell density was $5 \times 10^{6}$ cells $/ \mathrm{ml}$. IF means fractions obtained from ion exchange chromatography with DEAE sephacel. Data are assayed using ANOVA. The results are expressed as the mean value \pm S.E. obtained from six separated mice. 

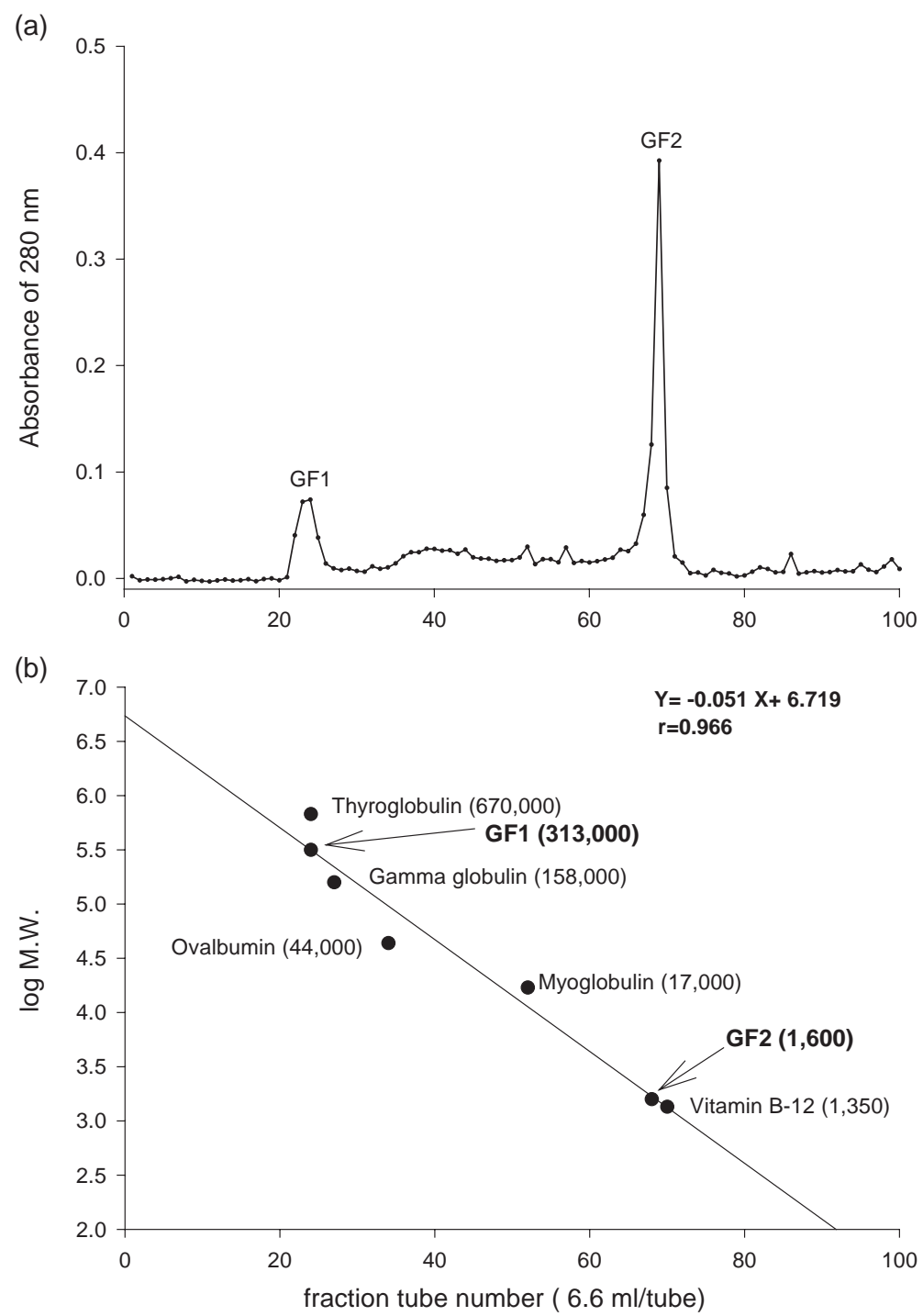

Fig. 6. (a) Gel-filtrated chromatogram of IF4 with Sepharose CL-6B and (b) calibrated with standard molecular weight kit. The column (2.6 $\mathrm{cm} \times 100 \mathrm{~cm}$ ) was eluted with deionized water at a flow rate of $1.3 \mathrm{ml} / \mathrm{min}$.

molecular weight of GF1 and GF2 were $313 \mathrm{kDa}$ and $1.6 \mathrm{kDa}$, respectively (Fig. 6b). It was found that GF1 was the major fraction attributing to immuno-stimulating response. The stimulation index (S.I.) for GF1 in the range of $0.5 \sim 5.0 \mu \mathrm{g} / \mathrm{ml}$ showed a dose response effect on BALB/c splenocytes (Fig. 7). The S.I. to $\mathrm{BALB} / \mathrm{c}$ mice stimulated using GF1 at the concentration of $5.0 \mu \mathrm{g} / \mathrm{ml}$ was $4.81 \pm 0.07$, while S.I. stimulated by crude WASWE at the concentration of $1250 \mu \mathrm{g} / \mathrm{ml}$ was $3.94 \pm 0.18$ (Fig. 1). The WASWE's immuno-stimulating activity increased more than 300 times after it was purified from crude-extraction to using gel filtration treatment.

\subsubsection{Bioactive substances with immuno-stimulation in WASWE characterization}

Table 2 summarized the stimulation index, purification fold, protein content and WASWE yield produced by different purification processes. The S.I. of the crude extract (WASWE), IF4 and GF1 to 


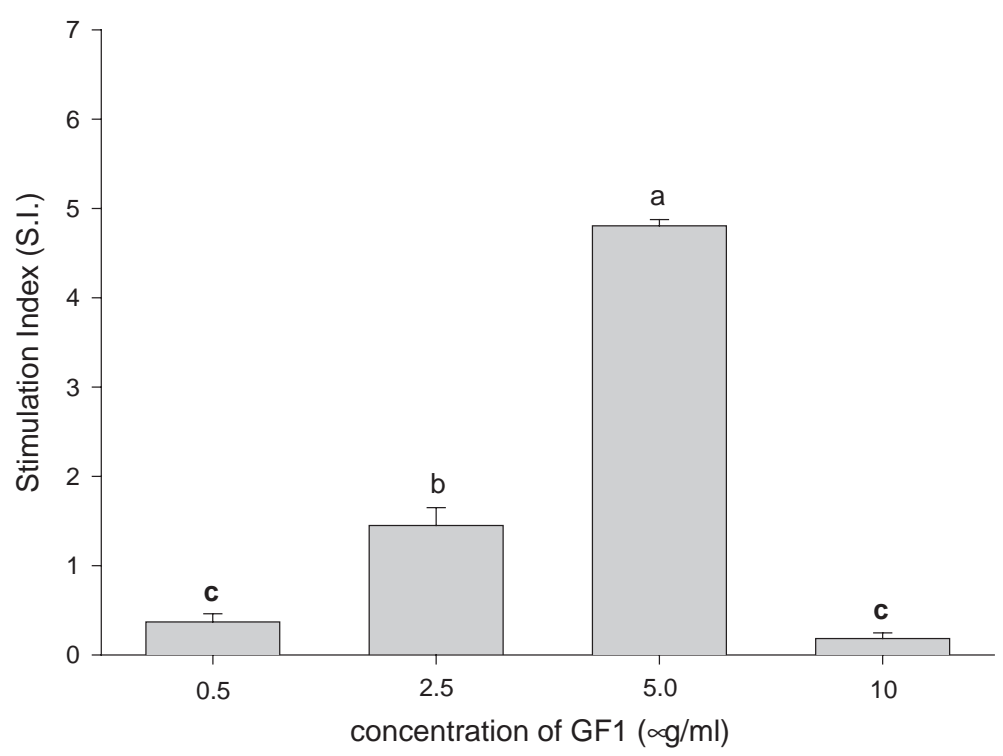

Fig. 7. Stimulation index (S.I.) to total splenocytes incubated with the gel-filtrated fraction 1 (GF1) from WASWE at various concentrations for $72 \mathrm{~h}$ at $37^{\circ} \mathrm{C}$. Original cell density was $2.5 \times 10^{6} \mathrm{cells} / \mathrm{ml}$. Data are assayed using ANOVA. Each bar represents the mean value \pm S.E. obtained from three separated mice. Within each bars graph, bars not sharing a letter are significantly different $(P<0.05)$ according to Duncan's New Multiple Range test.

splenocytes at the same corresponding concentration of $1250 \mu \mathrm{g} / \mathrm{ml}$ were $3.9,6.8$, and 1203 , respectively. The stimulatory activity increased 309 times after WASWE was purified with gel filtration. The protein content of GF1 was $90.8 \%$. Yields of crude extract, ion exchange and gel filtration chromatography were calculated by the recovery of each individual step of the purification process and expressed as recovery in grams of powder per 100 grams of fresh vegetables, per 100 grams of WASWE and per 100 grams of IF4, respectively. The yields of WEWAS, IF4 and GF1 were $4.7 \%, 1.9 \%$ and $24.9 \%$, respectively. The yields seemed variable in different purification processes.

\section{Discussion}

There has been a rapid development in the use of herbal medicines in recent years around the globe. Many researches have focused on exploring the immuno-stimulating actions of certain foods and dietary herbs. It has been found that Lactobacillus delbrueckii subsp. bulgaricus and Lactobacillus acidophilus mitogenically induced antibody production and spleen cell proliferation [22]. Aqueous extracts of Crinum latifoliumect and Camellia sinensis, Chinese and Vietnamese traditional medicines, show immunomodulatory properties on human peripheral blood mononuclear cells [23]. In our early studies, we found that dehulled adlay, a food and natural Chinese medicine, demonstrated antiallergic activities [24]. However, some Cruciferous and Brassica vegetables inhibited tumor proliferation and induced apoptosis $[25,26]$. These plants seemed to have adverse effects on cell-mediated and humoral immunity. We investigated wild $A$. spinosus which is served as vegetables or herbs in Taiwan, for its immuno-modulatory actions using primary spleen cell cultures from $\mathrm{BALB} / \mathrm{c}$ mice. There is no known report on immuno-modulation concerning A. spinosus. Our results provide evidence that wild $A$. spinosus water extract (WASWE) demonstrates significant $(P<0.01)$ immuno-stimulating activity on primary splenocytes from female BALB/c mice (Fig. 1).

Knowledge of which specific cell subpopulations were being stimulated was very important for future use in immuno-pharmacology. Our results indicate that WASWE exerts stimulatory effects on both B and T cells (Fig. 2). However, bulk splenocytes stimulated 
by an adequate concentration $(1250 \mu \mathrm{g} / \mathrm{ml})$ of WASWE exhibited a much higher proliferation rate than that of isolated purified B and T cells (Table 1). This suggests some interactions between these two cells. We assumed that $\mathrm{T}$ cells in bulk splenocytes are activated via secondary signaling from stimulated B cells, leading to the $\mathrm{T}$ cell proliferation. It has been found that $\mathrm{B}$ lymphocytes may act as antigenpresenting cells for CD4+ $\mathrm{T}$ cell priming if $\mathrm{B}$ cell and $T$ cell coexist [27]. Resting B lymphocytes were also found to act as APC for naive T lymphocytes via CD40 ligand/CD40 interaction [21]. When it is activated, $\mathrm{T}$ helper cell-related cytokines may interplay with B cells and direct their differentiations [28]. $\mathrm{B}$ cell interactions with activated $\mathrm{T}$ cells reduce the threshold for CD40-mediated B cell activation [29]. We provide evidence that WASWE directly stimulates the proliferation of B lymphocytes and suggest the possibility of activated B cells subsequently delivering a second signal to activate $\mathrm{T}$ cells. Actually we had found that WASWE stimulated both Th1 and Th2 cytokines production in vitro by splenocytes from female BALB/c mice, however the secretion of Th2 cytokines (IL-5, IL-6, IL-10) was much higher than that of Th1 cytokines (IL-2, IFN- $\gamma$ ) (data not shown). From the profiles of cell proliferation and cytokine production stimulated by WASWE in the splenocyte culture, this presumably occurs that WASWE first

Table 1

Stimulation index (S.I.) of WASWE to different lymphocyte proliferation isolated from the spleen of female BALB/c mice

\begin{tabular}{lccc}
\hline & \multicolumn{3}{c}{ Stimulation index (S.I.) } \\
\cline { 2 - 4 } & $\begin{array}{l}\text { Total splenocytes } \\
\text { (B cell: 41.54\%; }\end{array}$ & $\begin{array}{l}\text { Isolated } \\
\text { B cell (B cell: }\end{array}$ & $\begin{array}{l}\text { Isolated } \\
\text { T cell (T cell: } \\
\end{array}$ \\
& T cell: 47.11\%) & $82.34 \%)$ & $88.85 \%)$ \\
\hline WASWE & 6.00 & 2.08 & 0.99 \\
$\quad(1250 \mu \mathrm{g} / \mathrm{ml})$ & & & \\
WASWE & 2.50 & 4.85 & -0.41 \\
$\quad(2500 \mu \mathrm{g} / \mathrm{ml})$ & & & \\
LPS $(5 \mu \mathrm{g} / \mathrm{ml})$ & 154.93 & 573.83 & 3.47 \\
PHA $(10 \mu \mathrm{g} / \mathrm{ml})$ & 344.43 & 19.63 & 72.09 \\
\hline
\end{tabular}

1. Stimulation index $=\left(\right.$ sample $_{\mathrm{cpm}}-$ blank $\left._{\mathrm{cpm}}\right) /\left(\operatorname{control}_{\mathrm{cpm}}-\mathrm{blank}_{\mathrm{cpm}}\right)$. 2. All values means of triplicates.

3. Original cell density: $2.0 \times 10^{6}$ cells $/ \mathrm{ml}$.

4. Total splenocytes were directly obtained from female BALB/c mice. Isolated B cells were obtained after they were treated using the complement lysis method. Isolated $\mathrm{T}$ cells were enriched in a nylon wool column.
Table 2

Changes in stimulation index, stimulatory activity, protein content and WASWE yield during different purification processes

\begin{tabular}{lccc}
\hline Purified process & $\begin{array}{l}\text { Crude } \\
\text { extract }\end{array}$ & $\begin{array}{l}\text { Ion exchange } \\
\text { (IF4) }\end{array}$ & $\begin{array}{l}\text { Gel filtration } \\
\text { (GF1) }\end{array}$ \\
\hline Stimulation index $^{\mathrm{a}}$ & 3.9 & 6.8 & 1203 \\
Stimulatory activity $^{\mathrm{b}}$ & 1.0 & 1.7 & 309 \\
Protein content $^{\mathrm{b}}(\%)$ & 79.0 & 10.4 & 90.8 \\
Yield $^{\mathrm{c}}(\%)$ & 4.7 & 1.9 & 24.9 \\
\hline
\end{tabular}

${ }^{\text {a }}$ Calculated by the maximum splenocyte proliferation rate of $\mathrm{BALB} / \mathrm{c}$ mice at the same corresponding concentration of $1250 \mu \mathrm{g}$.

b The protein content of lyophilized powder was assayed by the BCA protein kit.

${ }^{c}$ Calculated by the recovery of each individual step of the purification process.

activates B cells and the activated B cells subsequently activate $\mathrm{T}$ cells especially $\mathrm{Th} 2$ cells. After they are activated, both Th1 and Th2 cells, especially Th2 cells (cytokines), can reversely contribute to humoral immunity by inducing B cells to proliferate, differentiate or produce antibodies. However, the extracts from Aeginetia indica Roxbert demonstrate a $\mathrm{T}$ cell stimulatory activity in vivo [7]. Our results suggest that different immuno-modulatory principles might exert diverse mechanisms on both humoral and cellular immune responses. Certain herbal medicinal ingredients affect the peripheral lymphocyte proliferation and serum antibody titer [12], so that WASWE bioactive ingredients may have potential for use as a component in new immuno-potentiator drugs.

It is necessary to unravel the basic characterization of the immuno-stimulating constituents in WASWE for future applications in dietary supplements or advanced clinical practice tests. In our preliminary studies on A. spinosus, we found that heat-treated WASWE lost its immuno-stimulating activity, while activated charcoal-treated WASWE increased immuno-stimulating activity (data not shown). The preliminary results indicated that the bioactive constituent in WASWE might be a proteinaceous component with higher molecular weight. Activated charcoal adsorbs colorants (like flavonoids) and some lower molecular weight substances. Most proteinaceous substances are heat-labile. In this study, we found a novel immuno-stimulating substance in WASWE with a molecular weight of $313 \mathrm{kDa}$ (Fig. 6b) containing $90.8 \%$ (Table 2) protein. The immuno-stimulating activity of this novel protein increased 309 times as 
compared to that of crude WASWE. As we indicated in the part of materials and methods, the protein content was determined by the BCA method in this study. The results from the BCA method seem protein-to-protein variation and are interfered by the constitutes, such as reducing sugars and reducing agents, thiols, copper chelating agents, ascorbic acid and uric acid, tyrosine, cysteine and tryptophan. Using bovine serum albumin (BSA) or immunoglobulin (IgG), especially BSA, as standards works well with most protein assay methods. To minimize the confounding of protein type, the BSA was used as a standard protein for quantitation of total protein content in this study. Besides, most interfering substances against protein determination are small molecules. They might not be obtained from gel filtration column in our experimental condition. To further minimize the confounding of water content, the samples used for protein determination were lyophilized to remove water in this study. Because the other constitutes of GF1 should not disturb the protein determination, we assume that the BCA method is a suitable and believable method for protein determination in our study. The BCA method has also been referred by other reports [5,30]. This study shows that the protein content of GF1 is $90.8 \%$. Most proteins extracted from plants are finally proved to be a glycoprotein. We assume that GF1 is a glycoprotein and the heat-labile property of GF1 might be attributed to its high protein content. The active principles extracted from shark cartilage are thermally stable proteoglycans with molecular masses exceeding $100 \mathrm{kDa}$. They are potent $\mathrm{B}$ cell stimulators but they do not affect $\mathrm{T}$ cells [5]. However, basic properties between the novel proteins from WASWE and from shark cartilage are quiet different. The stability of proteoglycans is a reflection of the fact that the protein core is shielded by surrounding glycosaminoglycan chains but this is not the case of GF1. More information on the basic properties concerning the immuno-stimulating protein in WASWE remains to be elucidated.

This study showed that a novel protein with a molecular weight of $313 \mathrm{kDa}$ displayed strong immuno-stimulating activity, and could directly activate primary B cell proliferation. This is a potentially valuable substance for nutraceutical or immunopharmacological use.

\section{Acknowledgements}

This study was supported by grants from the National Science Council (NSC89-2312-B-002-012), Executive Yuan, Republic of China (ROC).

\section{References}

[1] Ameho CK, Adjei AA, Yamauchi K, Harrison EK, Kulkarni $\mathrm{AD}$, Sato $\mathrm{S}$, et al. Modulation of age-related changes in immune functions of protein-deficient senescence-accelerated mice by dietary nucleoside-nucleotide mixture supplementation. Br J Nutr 1997; 77:795-804.

[2] Carver JD. Dietary nucleotides: cellular immune, intestinal and hepatic system effects. J Nutr 1994;124:144s-8s.

[3] Chandra RK. Effect of macro- and micronutrient deficiencies and excesses on immune response. Food Technol 1985;36: $91-3$.

[4] Kumari BS, Chandra RK. Over-nutrition and immune responses. Nutr Res 1993;13:s3-18.

[5] Kralovec JA, Guan Y, Metera K, Carr RI. Immunomodulating principles from shark cartilage: Part 1. Isolation and biological assessment in vitro. Int Immunopharmacol 2003;3: 657-69.

[6] Villasenor-Garcia MM, Lozoya X, Osuna-Torres L, ViverosParedes JM, Sandoval-Ramirez L, Puebla-Perez AM. Effect of Ginkgo biloba extract EGb 761 on the nonspecific and humoral immune responses in a hypothalamic-pituitary-adrenal axis activation model. Int Immunopharmacol 2004;4:1217-22.

[7] Auttachoat W, Chitsomboon B, Peachee VL, Guo TL, White Jr KL. Immunomodulation by Dok Din Daeng (Aeginetia indica Roxb.) extracts in female B6C3F1 mice: (I). Stimulation of T cells. Int Immunopharmacol 2004;4:1367-79.

[8] Baral R, Chattopadhyay U. Neem (Azadirachta indica) leaf mediated immune activation causes prophylactic growth inhibition of murine Ehlich carcinoma and B16 melanoma. Int Immunopharmacol 2004;4:355-66.

[9] Kim MJ, Kim HN, Kang KS, Baek NI, Kim DK, Kim YS, et al. Methanol extract of Dioscoreae rhizoma inhibits proinflammatory cytokines and mediators in the synoviocytes of rheumatoid arthritis. Int Immunopharmacol 2004;4: 1489-97.

[10] Kao ST, Wang SD, Wang JY, Yu CK, Lei HY. The effect of Chinese herbal medicine, xiao-qing-long tang (XQLT) on allergen-induced bronchial inflammation in mite-sensitized mice. Allergy 2000;55:1127-33.

[11] Nagai T, Arai Y, Emori M, Nunome SY, Yabe T, Takeda T, et al. Anti-allergic activity of a Kampo (Japanese herbal) medicine "Sho-seiryu-to (Xiao-Qing-Long-Tang)" on airway inflammation in a mouse model. Int Immunopharmacol 2004; 4:1353-65.

[12] Kong X, Hu Y, Rui R, Wang D, Li X. Effects of Chinese herbal medicinal ingredients on peripheral lymphocyte proliferation and serum antibody titer after vaccination in chicken. Int Immunopharmacol 2004;4:975-82. 
[13] Kong ZL, Lin YH, Feng KK. Regulation of immune cell functions by hot water extract of hard clam. Nutr Sci J 1996; 21:421-31.

[14] Yamada K, Ikeda I, Sugahara T, Shirahata S, Murakami H. Screening of immunoglobulin production stimulating factor (IPSF) in foodstuffs using human-human hybridoma HB4C5 cells. Agric Biol Chem 1989;53:2987-91.

[15] Jaramillo A, Sonnenfeld G. Potentiation of lymphocyte proliferative responses by nickel sulfide. Oncology 1992;49: $396-406$.

[16] Stevens MG, Olsen SC, Pugh Jr GW. Comparison of spleen cell proliferation in response to Brucella abortus 2308 lipopolysaccharide or proteins in mice vaccinated with strain 19 or RB51. Infect Immun 1995;63:319-25.

[17] Gridley DS, Shultz TD, Stickney DR, Slater JM. In vivo and in vitro stimulation of cell-mediated immunity by vitamin B-6. Nutr Res 1988;8:201-7.

[18] Kantha SS, Tayor CE, Ross AC. The impact of Vitamin A deficiency and repletion with retinol and $\beta$-carotene on concanavalin A-induced lymphocyte proliferation. Nutr Res 1992;12:1527-39.

[19] Akashi T, Nagafuchi S, Anzai K, Kitamura D, Wang J, Taniuchi I, et al. Proliferation of $\mathrm{CD}^{+}{ }^{+} \mathrm{B} 220^{+}$single-positive normal $\mathrm{T}$ cells was suppressed in B-cell-deficient $l p r$ mice. Immunology 1998;93:238-48.

[20] Seddigheh RB, Edwards B, Sopori ML. Lead stimulates lymphocyte proliferation through enhanced $\mathrm{T}$ cell-B cell interaction. J Pharmacol Exp Ther 1999;288:714-9.

[21] Evans DE, Munks MW, Purkerson JM, Parker DC. Resting B lymphocytes as APC for naïve T lymphocytes: dependence on CD40 ligand/CD40. J Immunol 2000;164:688-97.

[22] Easo JG, Measham JD, Munroe J, Green-Johnson JM. Immunomodulatory actions of lactobacilli: mitogenic induc- tion of antibody production and spleen cell proliferation by Lactobacillus delbrueckii subsp. bulgaricus and Lactobacillus acidophilus. Food Agric Immunol 2002;14:73-83.

[23] Zvetkova E, Wirleitner B, Tram NT, Schennach H, Fuchs D. Aqueous extracts of Crinum latifolium (L.) and Camellia sinensis show immunomodulatory properties in human peripheral blood mononuclear cells. Int Immunopharmacol 2001; $1: 2143-50$.

[24] Hsu HY, Lin BF, Lin JY, Kuo CC, Chiang W. Suppression of allergic reactions by dehulled adlay in association with the balance of Th1/Th2 cell responses. J Agric Food Chem 2003; $51: 3763-9$.

[25] Smith TK, Mithen R, Johnson IT. Effects of Brassica vegetable juice on the induction of apoptosis and aberrant crypt foci in rat colonic mucosal crypts in vivo. Carcinogenesis 2003;24:491-5.

[26] Xiao D, Srivastava SK, Lew KL, Zeng Y, Hershberger P, Johnson CS, et al. Allyl isothiocyanate, a constituent of Cruciferous vegetables, inhibits proliferation of human prostate cancer cells by causing $\mathrm{G} 2 / \mathrm{M}$ arrest and inducing apoptosis. Carcinogenesis 2003;24:891-7.

[27] Constant SL. B lymphocytes as antigen-presenting cells for $\mathrm{CD}^{+}{ }^{+} \mathrm{T}$ cell priming in vivo. J Immunol 1999;162:5695-703.

[28] Gagro A, Gordon J. The interplay between T helper subset cytokines and IL-12 in directing human B lymphocyte differentiation. Eur J Immunol 1999;29:3369-79.

[29] Klaus GG, Holman M, Johnson-Leger C, Chistenson JR, Kehy MR. Interaction of $\mathrm{B}$ cells with activated $\mathrm{T}$ cells reduces the threshold for CD40-mediated B cell activation. Int Immunol 1999;11:71-9.

[30] Smith PK, Krohn RL, Hermanson GT, Mallia AK, Gartner FH, Provenzano MD, et al. Measurement of protein using bicinchoninic acid. Anal Biochem 1985;150:76-85. 